\title{
Deficiencies within the education system with regard to perceptual motor learning preparation of Grade R learners
}

\begin{abstract}
Increased concern about the low levels of literacy and numeracy among Grade 3 learners in South Africa is resulting in more emphasis being placed on the preparatory Grade $R$ year. The level of learning readiness of pupils when entering formal teaching in Grade 1 is determined by perceptual motor stimulation that pupils received during the preschool phase. 'Learning readiness' can be influenced by the knowledge of teachers, teacher/child ratio, the availability of teaching aids, as well as the amount of space and time allocated to movement activities. The aim of the study recounted in this article was to determine the physical deficiencies that could negatively affect children's perceptual motor development and school readiness. Focus was placed on factors that influence perceptual motor development such as the training of teachers, availability of equipment and resources at schools with Grade R classes. Demographic information was collected with regards to; the qualification of teachers, the number of pupils, and intervention programmes that are offered at schools by outside institutions. A Likert scale questionnaire, with a combination of yes/no and open questions, was used and followed up by a personal interview. According to availability, 31 schools and 51 teachers were selected to participate in the research. Teachers of schools in developed areas and disadvantaged areas were involved in the study. The results of the study show that teachers are not sufficiently trained for the early child developmental needs within the education environment and that many schools are under-supplied in terms of resources and equipment. It is recommended that these teachers receive inservice training on learners' perceptual motor development and that the Department of Education should provide schools with resources and equipment to prevent these deficiencies in the education system.
\end{abstract}

Keywords: early childhood development (ECD), Grade R learners, learning readiness, perceptual motor development, teacher qualification, equipment, resources

Myrtle Erasmus, North-West University.E-mail: Myrtle.Erasmus@nwu.ac.za. Ona J. van Rensburg, North-West University.E-mail:11089822@nwu.ac.za. Anita E. Pienaar, North-West University.E-mail: anita.pienaar@nwu.ac.za. Suria Ellis, North-West University. E-mail: suria.ellis@nwu.ac.za.

South African Journal of Childhood Education | 2011 1(2): 46-63 | ISSN: 2223-7674 | $\odot$ UJ
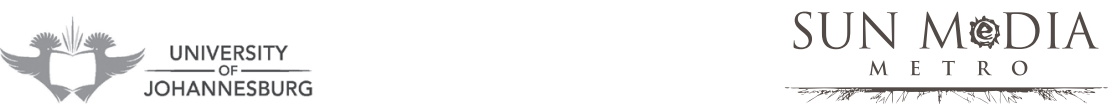


\section{Introduction}

Outcomes-based education has been implemented in schools across South Africa since 1998. The National Education Policy (Department of Education, 1997) regards early childhood development (ECD) as an umbrella term that refers to the development processes that children go through from birth to nine years of age. This phase of development process includes: physical, mental, emotional, moral and social growth. As the Department of Education (DoE) regards the first year (Grade R) as an introductory year of an integrated foundation of four years, the type of education pupils in Grade $R$ receive is of cardinal importance to their further school careers (DoE, 1997). During these first four years of school, the foundation is laid on which all further education and learning is built. As a result, children with a deficient foundation can experience problems throughout their school career (Willenberg, 2005). The standard of education and training in South Africa, which is reflected (among others) in the low pass rate of learners in Grade 12, is a cause for alarm. The statistics reflect back to the foundations laid in the Foundation Phase (Niebuhr, 2007).

\section{Aim and problem statement}

Usually, children attend preschool from three to six years of age. This period of time is critical to the development of fundamental movement skills (Gallahue \& Donnely, 2003). Because most young children are naturally curious and love to play and explore, these fundamental movement skills are learned very easily (Cools, De Martelaar, Samaey \& Andries, 2009).

According to Van Zyl (2004) there is a relationship between the school readiness and perceptual development of learners and the success that they reach in the later years. Although the National Department of Education formed policies to introduce Grade $\mathrm{R}$ classes to all primary schools, it is taking time to implement this into practice. The original goal was to have all children of five years, in a Grade R class in 2010, but it did not happen because not enough classrooms and qualified teachers were available. This target was subsequently postponed to 2014 by President Zuma (Zuma, 2009; Rademeyer, 2010).

\section{Research problem}

The situation in primary schools is that many teachers in Grade $\mathrm{R}$ classes are not adequately qualified. The teaching approach is too formal and Grade $\mathrm{R}$ classes follow the same timetable as the rest of the primary school. Grade R classrooms are not equipped for informal education with the necessary educational equipment. Most primary schools do not have a separate fenced play ground with jungle gyms and sandpits for Grade R learners. Many children in South Africa enter school without sufficient, if any, stimulation prior to formal schooling. It, for this reason, became necessary to give more attention to organised structures and schemes, such as Grade $R$ 
classes, to provide opportunities for more children to be exposed to preparation in order to reach learning readiness.

Another problem is that most primary school principals do not have the background knowledge or exposure about early childhood development and informal teaching practice of children of four to six years (Greyling, 2011). Due to this, they find it difficult to do justice to the newly acquired and instituted Grade $\mathrm{R}$ classes. All primary schools setups and school grounds are not equipped to adapt to the needs of Grade $R$ learners. There are not enough, or sufficiently trained teachers available, to take care of Grade R classes in primary schools (Steyn \& Hartell, 2011). If teachers, not trained to teach Grade R, are made responsible for young learners, they tend to follow a formal approach that is unsuitable for five to six year olds (Greyling, 2011). These children still need stimulation to be become ready for formal learning and for becoming schoolready. Many schools also do not have teaching aids or resources for Grade R classes. In some cases where schools have educational toys, games and aids, teachers do not know how to use the equipment (Erasmus, 2008).

In most of the schools observed the Grade R classes follow the same timetable as the rest of the primary school (Erasmus 2008). Such programmes included long times in classrooms spent completing worksheets. Young children need enough time for free play and movement activities, which are often restricted when following strict timetables suitable to older learners (Greyling, 2011).

The aim of the research reported in this article was to determine the deficiencies within the education system with regard to perceptual motor learning readiness of Grade $\mathrm{R}$ learners in two previous disadvantaged schools in the Dr Kenneth Kaunda district in the North-West Province. The research focused on the following core aspects: Qualifications of teachers and time spent on movement by learners (structured and unstructured), classroom size and outside space, equipment and resources available at schools and the teacher/child ratio. The phenomenon, namely deficiencies within an education environment with regard to perceptual motor learning preparation of Grade R learners, as found in the North-West Province, was researched.

\section{Description of concepts}

\section{Teacher qualifications}

The DoE requires a degree or a three-year diploma in early childhood education as adequate training for Grade $\mathrm{R}$ teachers.

\section{Grade R classroom and outside playground}

Grade $\mathrm{R}$ classrooms are suppose to be informally furnished with appropriate equipment, educational toys, and designated activity areas (that stimulate creative thinking, construction, fantasy, and manipulation). The Grade $\mathrm{R}$ group should have a separately fenced play ground with at least a jungle gym and sandpit. 


\section{Background on circumstances in South Africa}

South Africa is regarded as a developing country with many factors that contribute to the current state of national education. Various factors, such as too few schools, too few teachers and many learners who do not have access to education contribute to the concern over Foundation Phase education, which forms the concrete conceptual basis of all education. This concern is addressed in the "Education White paper 5 on early childhood development" (1995) where the importance of early childhood development is emphasised. It also sets norms and standards for the training of ECD educators (DoE, 2007). Kader Asmal, former minister of education, had already indicated in 2001 that more than $40 \%$ of all children in South Africa grow up in poverty and neglect, and that only 450000 of the approximate 960000 children between the age of five and six years have access to some or other early childhood development programme. Compulsory systemic assessment of learners, which began in 1998 with Outcomes Based Education (OBE), indicated a mean numeracy level of $30 \%$ and a mean literacy level of $54 \%$ in 2000, in a sample of Grade 3 learners who were involved in the assessment. In terms of literacy, reading and writing skills exhibited mean values of 39\% (DoE, 2002). The findings of a second systemic assessment in 2007 did not show much improvement (Pandor, 2008; DoE, 2008). In the second assessment, a mean for literacy was indicated as $36 \%$ and $35 \%$ for numeracy (Serrao, 2008).

It was also found that in certain parts of South Africa $25 \%$ of learners from previously disadvantaged groups did not pass Grade 1. These data demonstrate the pressing need for correct and sufficient stimulation and intervention for school beginners. Poorly developed perception, as well as gross and fine muscle coordination, must already receive the necessary attention in Grade $R$. Since Grade $R$ has become part of the Foundation Phase, learners must achieve certain outcomes in all eight subjects, as is prescribed by the National Curriculum Statement (NCS) (DoE, 2002).

Many schools have already instituted a Grade $\mathrm{R}$ class, but in many cases the teachers who offer these classes are not qualified to teach in the ECD phase. Although the reasons for this can be considered as varied and complex, it seems if few native African language speakers are prepared or willing to be trained to teach classes in the Foundation Phase level of education. Evidence in this regard shows that African school leavers do not consider helping primary school pupils to read and write (Govender, 2011), while university statistics show that African trainee teachers rather opt to teach high school pupils instead of their younger counterparts. Robinson, Dean of Cape Peninsula University of Technology, furthermore comments that African students perceived Foundation Phase teaching to be a low-status career (2011), while the Department of Higher Education and Training (DHET) furthermore predicts that of the 1275 Foundation Phase students expected to graduate at the end of 2009, only 168 were African students (DHET, 2009). From this it would appear that the value of a firm foundation that is established in the Foundation Phase by good teachers is not often recognised and a qualification in ECD is hence regarded as inferior, resulting in young people being reluctant to become Foundation Phase teachers (Lenyai, 2009). 
In previously disadvantaged communities, housing space is limited, while the possibility of movement and playing areas is restricted (Erasmus, 2008). This also applies to schools with overcrowded classrooms, little or no equipment and poorly qualified teaching staff: the phenomenon of deprivation with regard to development is currently being repeated (Ministerial Committee on Rural Education, 2005).

According to the outcomes set for Grade $\mathrm{R}$ learners, with regard to movement and physical development (DoE, 2003), there should be sufficient space and opportunities at schools with Grade R classes for these activities. Various activities, such as running, chasing and evasion games and various ways of moving (e.g. spinning around in a circle, lifting and balancing an object and expressive movements with various parts of the body) must be offered.

Results of a study in South Africa by Labuschagne (2006, p. 77) on the motor and sensory development of five and six year-olds from poor socio-economic conditions indicated developmental deficiencies of as much as 12 months. Differences were also indicated in the developmental levels of girls and boys, of which perceptual and motor deficiencies appear to be the most significant. This concurs with research conducted by Goodway and Branta (2003), which showed that less privileged children experience developmental deficiencies with regard to fundamental school readiness skills. Research found a correlation between socio-economic levels, degree of nutrition and developmental skills among children aged two to six years, from urban and rural environments in Israel and in India (Shula, Chaya, Jeri \& Noomi, 2000). Physical activities in children are advantageous to their health and provide a strong platform for maintaining good health throughout life.

Although gross and fine motor skills and perceptual development are an integral, inseparable development process, the fine motor development of children is preceded by gross motor development; just as a small child's sitting, crawling and walking actions follow in sequence (Grové \& Hauptfleisch, 1978). These stages follow a predictable sequence that is commonly age related, and provide a convenient way to arrange general guidelines of motor development (Gallahue \& Ozmun, 1995).

Even though there are clear learning outcomes and assessment standards in the NCS, many schools do not apply them as a result of limited facilities and ignorance, or lack of training or interest by teachers. Regardless of the fact that the NCS makes provision for education, stimulation and promotion of physical development, movement and perceptual development of Grade R learners, it is not implemented at all schools and offered on a regular basis. This is partly due to unqualified teachers and insufficient, funding, equipment and apparatus. In these classes more emphasis is placed on completing the formal work cards (that is, two-dimensional works) than on physical, motor and perceptual discovery playing opportunities (De Witt, 2009; Davin \& Van Staden, 2004). This leads to frustration in the small child who, according to the Department of Education, does not, as yet, possess the fine motor abilities to colour in for long periods of time and to trace written patterns. If there could be a balance in the daily programme that Grade $\mathrm{R}$ learners follow between more active movement 
activities and passive fine motor/perceptual activities, it would be to the advantage of the small child (South African National Tutor Services, 2003).

\section{Theoretical foundation}

The research problem requires an approach that makes it possible to gather contextrelated responses. This should lead to better understanding of the phenomenon, while the researcher should gain insight into the perceptual motor preparation of Grade $R$ learners.

This research was undertaken with a post-positivistic and interpretivistic perspective in mind (Leedy \& Ormond, 2005). The post-positivistic perspective aims to conduct an empirical observation and measurement of the research phenomenon. It reflects the need to identify and assess the causes that influence outcomes, in this case the shortcomings within the education system with regard to perceptual motor learning preparation of Grade $\mathrm{R}$ learners. Interpretivism is applicable because the phenomenon includes the social reality, as well as the unique views and experiences of the participants. The effect of the negative influence of the bio-ecological context in which Grade R learners find themselves is self-evident.

The research further rests on the theory of Bronfenbrenner, which focuses on an ecosystemic model. According to Bronfenbrenner, there is an interaction in the bioecological context in which the learner finds him-/herself. The bio-ecological context can be advantageous or detrimental to the development of the learners (Donald, Lazarus \& Lolwana, 2002).

An empirical investigation was conducted with this conceptual-theoretical framework in mind.

\section{Empirical investigation}

\section{Research design}

A combination of quantitative and qualitative data collection and analysis was performed. A mixed method approach was used with the aim of using the best of each method. The combined method also strengthens the validity and reliability of this study (Creswell, 2009).

\section{Sampling}

Research data was obtained from an availability sample to include teacher participants of Grade R classes in the North-West Province. A category division was made of Grade $R$ classes at primary schools $(N=17)$ and Grade $R$ classes at nursery schools $(N=14)$. Grade $\mathrm{R}$ classes were further classified according to wealth and degree of communal development, i.e. from developed schools $(N=17)$ and previously disadvantaged schools $(N=14)$. According to the information obtained from the questionnaires, there 
were different categories identified where schools with Grade R classes were situated. Schools were further classified as primary and nursery schools with Grade R classes:

- $\quad$ Developed primary schools with Grade R classes: $(\mathrm{N}=5)$;

- $\quad$ Developed nursery schools with Grade R classes: $(\mathrm{N}=12)$;

- $\quad$ Disadvantaged primary schools with Grade R classes: $(\mathrm{N}=9)$; and

- $\quad$ Disadvantaged nursery schools with Grade R classes: $(\mathrm{N}=5)$.

An availability sample was selected of teachers of Grade $R$ classes in the North-West Province. Information was obtained from teachers $(\mathrm{N}=51)$ and the physical availability of sources at schools $(\mathrm{N}=31)$ by means of a questionnaire that was completed with individual Grade R teachers in schools.

\section{Measuring instrument}

A self-compiled questionnaire was used to determine the training and age of teachers and physical availability of sources and equipment at schools to stimulate perceptual and motor development. A pilot study was first performed using five teachers to test the suitability of the questions in the questionnaire after which improvements were made.

This study consisted of individual interviews with Grade $\mathrm{R}$ teachers during which qualitative information was obtained by means of a structured questionnaire at schools with Grade R classes. Questions on training, provision for movement development, size of classrooms and number of learners in class, the outdoor-playground, availability of playing equipment and resources were included in the questionnaire. The researcher asked the respondents questions directly from the questionnaire to obtain descriptive and explanatory information (Cohen et al., 2002). Individual interviews permitted the researcher to obtain personal information from teachers, which enabled the researcher to understand their day-to-day experiences and professional realities.

\section{Validity and reliability}

A questionnaire designed by the authors was used to obtain descriptive information. Cronbach's alpha reliability quotient is not applicable as each question was analysed separately. A researcher was present during the completion of the questionnaires to verify the correctness of the information, by means of observation, and to ensure the validity of the answers.

\section{Data collection}

Schools in the North-West Province of South Africa partook in the research. Questions on training, provision of movement development, classroom and playground size, availability of playing equipment and resources were included in the questionnaire. The researcher visited all 31 schools personally. Observation and individual interviews were used as qualitative and quantitative research methods (Creswell, 2009). 


\section{Data processing}

Data was analysed by using Statistica for Windows (Statsoft, 2010). Percentages, descriptive statistics, frequency tables and mean values were calculated. Two-way frequency tables were used to determine the correlation between developed and disadvantaged primary and nursery schools. Statistical significance was established on a $5 \%$ level of significance $(\mathrm{p}<0.05)$. In two-way frequency tables the phi-quotient was used to determine the practical significance of correlations (Ellis \& Steyn, 2003). A phi-quotient with values of 0.1 and smaller can be regarded as a small effect with no practical significance, while values of 0.3 as medium effect, which is visible in practice. Phi-quotient with values of 0.5 or larger is regarded as of great importance.

\section{Findings}

\section{Training of teachers}

For the analysis of the results obtained, the answers were categorised according to nursery and primary schools in developed and disadvantaged schools. Results with regard to perceptual motor learning preparing of Grade $\mathrm{R}$ learners were discussed.

A Spearman rank correlation was calculated between the training of teachers and their age $(r=-0.05)$, which indicated no statistical or practical significant correlations. $76 \%$ of the teachers' ages were between 30 and 50 years of age, and only $10 \%$ were in the 20 to 30 year category, which is an indication that there were few young teachers in the study population. This is an indication that the majority of Grade $\mathrm{R}$ teachers were mostly older people, which might be an advantage, considering that older teachers have more experience. There are not many young Grade $\mathrm{R}$ teachers. This suggests that, in the near future, there will not be enough teachers available for ECD education. No statistically significant differences were found with regard to the age of teachers in nursery and primary schools in developed and disadvantaged schools $(p=.29$ and $p=.52$, respectively). Table 1 and 2 provide information of the training of teachers, as obtained from the question used to determine whether the teacher is trained to offer preschool phase (ECD) education (Table 1), and what the nature of the qualification is (Table 2).

Table 1: Training of teachers

\begin{tabular}{|l|c|c|c|c|c|c|c|}
\hline & \multicolumn{3}{|c|}{ Trained } & \multicolumn{3}{c|}{ Not Trained } & \\
\hline School & $\begin{array}{c}\text { Nursery } \\
\text { N \& } \%\end{array}$ & $\begin{array}{c}\text { Primary } \\
\text { N \&\% }\end{array}$ & Total & $\begin{array}{c}\text { Nursery } \\
\text { N \& } \%\end{array}$ & $\begin{array}{c}\text { Primary } \\
\text { N \& \% }\end{array}$ & N \& \% & Total \\
\hline Developed school & $\mathrm{N}=5$ & $\mathrm{~N}=3$ & $\mathrm{~N}+$ & 4 & 7 & 11 & 29 \\
$79 \%$ & $30 \%$ & $18 \%$ & $21 \%$ & $70 \%$ & & \\
\hline Disadvantaged & 3 & 4 & 7 & 6 & 9 & 15 & 22 \\
school & $33 \%$ & $31 \%$ & & $67 \%$ & $69 \%$ & & \\
\hline Number of schools & & & & & 51 \\
\hline
\end{tabular}


No teacher in the group was found without any training (Table 1), although qualified teachers who did not possess the necessary ECD training were part of the group. There were also no teachers with further training past the four year Foundation Phase course. No teacher had obtained honours or master's degree, or a doctorate in ECD. More trained Grade $\mathrm{R}$ teachers, from the developed school group, work at nursery schools $(79 \%-P<0.01$, effect size phi $=0.41)$, whereas fewer Grade R teachers, with appropriate training, work at primary schools (30\%).

In disadvantaged schools no significant difference between nursery and primary schools could be observed, but more than two-thirds of the teachers did not have the necessary ECD training. A greater number of teachers in disadvantaged schools did not obtain the necessary training as compared to teachers from developed schools. The greater percentage of teachers in developed schools have three to four years of applicable ECD training (66\%), as compared to the $33-46 \%$ in disadvantaged schools that possess the minimum ECD qualifications. Teachers in disadvantaged schools with one or two years of training are, according to the National Qualification Framework levels, on levels 1 to 4 (NQF levels).

Table 2: Nature of teacher training

\begin{tabular}{|l|c|c|c|c|}
\hline \multirow{2}{*}{$\begin{array}{c}\text { Duration and nature of } \\
\text { training }\end{array}$} & \multicolumn{2}{|c|}{ Developed Schools } & \multicolumn{2}{c|}{ Disadvantaged Schools } \\
\cline { 2 - 5 } & Nursery & Primary & Nursery & Primary \\
\hline 1-year ECD certificate/diploma & 0 & 0 & 2 & 2 \\
\hline 2-year ECD certificate/diploma & $0 \%$ & $0 \%$ & $22 \%$ & $15 \%$ \\
\hline 3-year ECD certificate/diploma & $0 \%$ & 1 & $10 \%$ & 3 \\
\hline 3-year Foundation Phase/ & $5 \%$ & 0 & $0(0 \%)$ & 1 \\
\hline Junior Primary & 3 & 6 & & $8 \%$ \\
\hline 4-year Foundation Phase & $16 \%$ & $60 \%$ & $33 \%$ & 3 \\
(Gr. R, 1, 2, 3) & 15 & 3 & 3 & $23 \%$ \\
\hline Total schools 51 & $79 \%$ & $30 \%$ & $33 \%$ & 4 \\
\hline
\end{tabular}

Non-governmental institutions offer one to three years training in ECD, and $22 \%$ of trained teachers in the study obtained such a qualification. A further $30 \%$ are competent to teach Grade 1 to Grade 3, and possess a three-year Foundation Phase qualification, which excludes Grade R. Only 48\% of the teachers possess an appropriate University or Teachers' College qualification that equips them with the knowledge and skills to teach Grade R. Only 31\% of the teachers in the study acknowledged that their pupils were previously enrolled in a pre-primary school, nursery school or day-care centre. The importance of the appropriate training to teach Grade $\mathrm{R}$ is emphasised by the number of learners who do not receive the necessary exposure, or stimulation, before entering Grade R, to ensure learning readiness. For some of the learners it is the first 
time that they are exposed to informal and formal activities in a group context. The one-year EDC training, of which only $49 \%$ of the study population possessed sufficient training, is orientated towards the care of small children, and is not appropriate to stimulate learners in Grade $\mathrm{R}$ up to the level that is required for school readiness.

\section{Teacher-learner ratio}

Although there were no statistically significant differences in teacher-child ratios in nursery and primary schools in developed and disadvantaged schools $(9=0.11)$, the mean number of learners per teacher in disadvantaged schools is 31 as compared 27 in developed schools. Learner numbers in the different schools varied from nine learners per class, in very small one-man nursery schools, to 60 in disadvantaged schools. The mean ratio of teacher/learner in developed schools at nursery schools was 26 per teacher and 28 in primary schools. In disadvantaged schools there were 32 learners per teacher in the nursery schools and 31 in primary schools. The DoE does not indicate large differences between disadvantaged and developed schools. This mean ratio is also within the parameters that are recommended by the DoE.

\section{Time spent on inside and outside play and free play}

The next aspect, which can be considered as limiting to the full development of perceptual motor skills of Grade 1 learners, is the time spent on directed activities within and outside the classroom, as well as on free-time play. Table 3 contains the results in this regard.

Most of the schools (disadvantaged/developed) spend between 15 and 20 minutes on activities inside the classroom and some nursery schools spend $40-50$ minutes. In developed schools Grade $\mathrm{R}$ learners in primary schools spend significantly less time on classroom activities than nursery school children $(p=.04$, effect size phi $=0.53$ ). In disadvantaged schools there is no significant difference in time spent inside the classroom between nursery and primary schools $(p=0.38)$, and in general there was also no difference between the developed and disadvantaged schools ( $p=0.77$, phi $=0.15$ ). The norm is that Grade $R$ learners should have 45 minutes to an hour freetime play outside the classroom, as was prescribed before the OBE system was implemented.

No significant differences were found in time spent outside the classroom in primary schools or nursery schools in any of the developed or disadvantaged schools ( $p=0.14$ and 0.12 respectively). The children mostly spent between 15 and 30 minutes of playing outside. In developed schools, nursery school learners spent significantly more time on free-time playing than primary school children $(p=.0 .01$, effect size phi $=0.70$ ). In disadvantaged schools there was no significant difference in the time spent on free-time playing in primary and nursery schools $(p=0.14)$. In general the time spent on free-time playing at developed schools was more than at disadvantaged schools; the difference is of practical significance $(p=0.01$, phi $=0.65)$. In some instances time spent on free-time play at developed schools was more than 60 minutes per day. In 
disadvantaged schools most Grade R classes follow the same timetable as Grade 1 to 3 classes. In break time children get food from the school-feeding scheme that reduce free playtime. In some disadvantaged schools only 20 minutes free play per day was mentioned.

\section{Available space for playing and movement at schools}

It is clear that the space available in classrooms, and in outside playing areas, differs considerably from site to site.

No significant differences in the size of the classroom at primary and nursery schools were found in any of the developed, or disadvantaged schools ( $p=0.47$ and 0.92 respectively), and $77 \%$ of the schools have classroom areas smaller than 80 square metres. The outside playing area at schools was also determined by the questionnaire. Depending on the number of learners that each nursery school accommodates, some schools only had one Grade R class, whereas bigger schools accommodated up to six Grade R groups. The primary schools with a quintile 5-grading had separated fenced playing areas for Grade $R$ groups. The size of the playground varied from school to school-based on the number of Grade $R$ groups.

Primary schools with Grade $\mathrm{R}$ classes in previously disadvantaged areas and informal settlements had little equipment on the playground for the Grade R learners. In informal settlements, there were sometimes 30 children housed in a makeshift structure, which served as a nursery school and playgroup, and the outside playground was very small (Erasmus, 2008).

Regulations for fixed surfaces for inside and outside playing areas were determined before 1994 by the DoE. This is, however, not applicable in the current education system.

No significant difference in the outside playground for primary and nursery schools in any of the developed or disadvantaged schools were found $(p=0.79$ en 0.41 respectively). Developed schools did, however, possess larger outside playgrounds in general than disadvantaged schools $(p=0.04$, phi $=0.74)$. The playgrounds of developed schools (53\%) were greater than 900 square metres, while $64 \%$ of the disadvantaged schools were smaller than 600 square metres.

\section{Availability of apparatus and equipment at schools}

Table 3 indicates the percentage of schools that possessed none of the more important equipment that should be available. Table 4 indicates schools, which had no fixed structures. The movement activities indication that was requested of the schools can be subdivided into three groups: self-manufactured equipment ('bottle catchers' made from recycled plastic containers); equipment which is obtainable (waste materials like old/used tyres, wooden poles, concrete pipes); and equipment which can be bought or supplied by the education department. 
Table 3: Number and percentage of schools that do not possess any loose equipment

\begin{tabular}{|l|c|c|c|c|}
\hline \multirow{2}{*}{\multicolumn{1}{|c|}{ Equipment }} & \multicolumn{2}{|c|}{ Developed school } & \multicolumn{2}{c|}{ Disadvantaged School } \\
\cline { 2 - 5 } & Nursery & Primary & Nursery & Primary \\
\hline Push wheels & $2(17 \%)$ & $1(20 \%)$ & $1(20 \%)$ & $8(89 \%)$ \\
\hline Balance beam & $3(25 \%)$ & $1(20 \%)$ & $4(80 \%)$ & $7(78 \%) 9$ \\
\hline Loose tyres & $0(0 \%)$ & $0(0 \%)$ & $2(40 \%)$ & $5(56 \%)$ \\
\hline Bottle catchers & $4(33 \%)$ & $2(40 \%)$ & $3(60 \%)$ & $8(89 \%)$ \\
\hline Kick \& catch & $0(0 \%)$ & $0(0 \%)$ & $3(60 \%)$ & $9(100 \%)$ \\
\hline Go-carts/wagons & $3(25 \%)$ & $3(60 \%)$ & $4(80 \%)$ & $9(100 \%)$ \\
\hline Rackets & $1(8 \%)$ & $1(20 \%)$ & $3(60 \%)$ & $7(78 \%)$ \\
\hline Crates/chests & $5(42 \%)$ & $3(60 \%)$ & $4(80 \%)$ & $7(78 \%)$ \\
\hline Boxing bag & $2(17 \%)$ & $2(40 \%)$ & $4(80 \%)$ & $9(100 \%)$ \\
\hline Hoops & $0(0 \%)$ & $0(0 \%)$ & $2(40 \%)$ & $6(67 \%)$ \\
\hline Hobby horses & $4(33 \%)$ & $5(100 \%)$ & $4(80 \%)$ & $9(100 \%)$ \\
\hline Sticks/pipes & $7(58 \%)$ & $5(100 \%)$ & $5(100 \%)$ & $8(89 \%)$ \\
\hline Skipping ropes & $1(8 \%)$ & $0(0 \%)$ & $0(0 \%)$ & $1(11 \%)$ \\
\hline Big balls & $0(0 \%)$ & $0(0 \%)$ & $2(40 \%)$ & $5(56 \%)$ \\
\hline Small balls & $0(0 \%)$ & $0(0 \%)$ & $2(40 \%)$ & $5(56 \%)$ \\
\hline Sand bags & $3(25 \%)$ & $2(40 \%)$ & $2(40 \%)$ & $5(56 \%)$ \\
\hline Material bags & $6(50 \%)$ & $2(40 \%)$ & $3(60 \%)$ & $8(89 \%)$ \\
\hline Moveable ladder & $7(58 \%)$ & $4(80 \%)$ & $4(80 \%)$ & $9(100 \%)$ \\
\hline & & & & \\
\hline
\end{tabular}

It is clear that although disadvantaged schools have a great need for this loose equipment; it is the poorer disadvantaged schools that have the least equipment.

Table 4: Number and percentage of areas with a great shortage of loose equipment

\begin{tabular}{|l|c|c|c|c|}
\hline \multirow{2}{*}{\multicolumn{1}{|c|}{ Equipment }} & \multicolumn{2}{|c|}{ Developed schools } & \multicolumn{2}{c|}{ Disadvantaged schools } \\
\cline { 2 - 5 } & Nursery & Primary & Nursery & Primary \\
\hline Small swing & $1(8 \%)$ & $2(40 \%)$ & $0(0 \%)$ & $6(67 \%)$ \\
\hline Large swing & $0(0 \%)$ & $1(20 \%)$ & $1(20 \%)$ & $7(78 \%)$ \\
\hline Balance beam - unstable & $3(25 \%)$ & $3(60 \%)$ & $3(60 \%)$ & $8(89 \%)$ \\
\hline Balance beam - stable & $2(17 \%)$ & $2(40 \%)$ & $3(60 \%)$ & $7(78 \%)$ \\
\hline See-saw & $5(42 \%)$ & $3(60 \%)$ & $3(60 \%)$ & $7(78 \%)$ \\
\hline Jungle gym & $0(0 \%)$ & $1(20 \%)$ & $1(20 \%)$ & $6(67 \%)$ \\
\hline Slide & $4(33 \%)$ & $2(40 \%)$ & $1(20 \%)$ & $7(78 \%)$ \\
\hline
\end{tabular}




\begin{tabular}{|l|c|c|c|c|}
\hline \multirow{2}{*}{\multicolumn{1}{|c|}{ Equipment }} & \multicolumn{2}{|c|}{ Developed schools } & \multicolumn{2}{c|}{ Disadvantaged schools } \\
\cline { 2 - 5 } & Nursery & Primary & Nursery & Primary \\
\hline Open area (running) & $3(25 \%)$ & $0(0 \%)$ & $2(40 \%)$ & $7(78 \%)$ \\
\hline Hanging bridge & $3(25 \%)$ & $4(80 \%)$ & $2(40 \%)$ & $9(100 \%$ \\
\hline Balancing boards & $3(25 \%)$ & $3(60 \%)$ & $1(20 \%)$ & $6(67 \%)$ \\
\hline Platform roundabout & $7(58 \%)$ & $4(80 \%)$ & $3(60 \%)$ & $8(89 \%)$ \\
\hline Slide & $3(25 \%)$ & $0(0 \%)$ & $4(80 \%)$ & $8(89 \%)$ \\
\hline
\end{tabular}

As is the case with the loose equipment, it is clear from Table 4 that although disadvantaged schools had a shortage of outside equipment, it is especially primary schools in these areas, which had practically no equipment. Skipping ropes were about the only equipment that was practically available everywhere.

Table 5: Number and percentage of schools without painted patterns

\begin{tabular}{|l|c|c|c|c|}
\hline & \multicolumn{2}{|c|}{ Developed schools } & \multicolumn{2}{c|}{ Disadvantage schools } \\
\hline & Nursery & Primary & Nursery & Primary \\
\hline Geometric shapes & $5(42 \%)$ & $2(40 \%)$ & $4(80 \%)$ & $8(89 \%)$ \\
\hline Lines & $6(50 \%)$ & $3(60 \%)$ & $4(80 \%)$ & $9(100 \%)$ \\
\hline Zigzag line & $6(50 \%)$ & $3(60 \%)$ & $4(80 \%)$ & $9(100 \%)$ \\
\hline Parallel lines & $9(75 \%)$ & $2(40 \%)$ & $4(80 \%)$ & $9(100 \%)$ \\
\hline Broken line & $9(75 \%)$ & $3(60 \%)$ & $5(100 \%)$ & $9(100 \%)$ \\
\hline Single footprints & $9(75 \%)$ & $2(40 \%)$ & $5(100 \%)$ & $9(100 \%)$ \\
\hline Footprint walking & $7(58 \%)$ & $4(80 \%)$ & $5(100 \%)$ & $9(100 \%)$ \\
\hline Hop scotch & $9(75 \%)$ & $2(40 \%)$ & $4(80 \%)$ & $9(100 \%)$ \\
\hline Cycle track & $2(17 \%)$ & $1(20 \%)$ & $0(0 \%)$ & $1(11 \%)$ \\
\hline
\end{tabular}

Table 5 indicates that $80 \%$ of nursery schools and $89 \%$ of primary schools in disadvantaged areas and $42 \%$ and $40 \%$ in developed schools respectively had no painted geometrical shapes. These patterns, which are especially important for perceptual motor development, can be made with little cost to the schools, as most of the schools possess cement surfaces. At developed schools more painted lines and footprints were found at primary schools than at nursery schools, while $75 \%$ of disadvantaged and $40 \%$ primary schools had no 'hop scotch' lanes. In the disadvantaged group no painted lines, footsteps and 'hop scotch' patterns were found at primary schools, while these lines/games were found at $20 \%$ of disadvantaged nursery schools, no footsteps or hop scotch lanes were found. No disadvantaged nursery school had a cycle lane, while one $(11 \%)$ disadvantaged primary school had a cycle lane. Two (17\%) developed nursery schools and one developed primary school had a cycle lane. 
Young children enjoy playing on lines and patters and learn skills such, as balancing and gross muscle coordination while they play. Cycling is advantageous to general muscle growth and balance development.

Various schools possessed equipment, which was not listed on the questionnaire. Equipment mentioned was large wooden constructions, outside dollhouses, tree houses, car wrecks with seats and steering wheel, 'cars' built of wood and avenues where gocarts can ride. Some schools had planted poles of various lengths to exercise balancing. Quintile 4 and 5 schools all had sand pits and were equipped to offer water games.

\section{Discussion of the results}

The aim of the investigation was to determine the presence of physical deficiencies that can hinder perceptual motor development and school readiness preparation of children. Deficiencies were identified in every aspect of the schooling of Grade Rs.

\section{Teacher training}

A large number of teachers did not possess the necessary training for teaching in Grade R and that influences the learners' perceptual motor development and therefore their learning readiness. Learning readiness in young children must be emphasised.

\section{Playing equipment and apparatus}

Schools in informal settlements and deprived communities exhibited a great deficiency in playing equipment and apparatus. As a result learners could not receive sufficient perceptual motor stimulation. At provincial level, the DoE already started supplying schools with playing apparatus in a limited capacity. Disadvantaged schools had a greater shortage of loose equipment, especially primary schools. Skipping ropes were the only apparatus that was available anywhere. Some of the schools had limited equipment and some of the teachers used their own equipment in classes. Some of the schools, especially in informal settlements and deprived neighbourhoods, had almost no equipment and did not have any developed outside playground with junglegym apparatus, swings and possessed limited movement areas.

\section{Time spent on physical activity}

Especially in primary schools, not enough time is spent on physical activity; both directed and free play activities.

\section{Recommendations}

The importance of ECD, which forms the basis upon which learning is built, must as a result be brought to the attention of school principals and school governing bodies. School principals must ensure that teachers, who are responsible for Grade R classes, receive the necessary training and that not any available teacher be used to teach 
Grade $\mathrm{R}$ classes. If the minister of basic education can set guidelines, the problem can be addressed and promoted at national level.

If movement development and physical activity were to take its proper place in the school programme, it would be to the advantage of the learners. In the report for the adaptation of the NCSs, as presented by the current minister of education, Angela Motshekga, physical education is prescribed as a subdivision of general studies and Foundation Phase learners must be exposed to it for at least two hours per week (DoE, 2009)

Factors that influence development, such as perception, spatial orientation, reasoning and understanding, coordination, gross and fine muscle development, as a result of deficiencies were identified in this study. These deficiencies can have a direct impact on the learning readiness of Grade $\mathrm{R}$ learners. It is recommended that principals must ensure that teachers, who are responsible for Grade $\mathrm{R}$ classes, receive the proper training to teach Grade $R$ learners and the DoE should supply schools with equipment and resources which will enable the promotion of learning readiness and that equipment and apparatus must be maintained. A further recommendation is that primary schools should have a separate fenced playground for Grade R to Grade 3 learners. The DoE is in the process of providing jungle gyms and other equipment for Foundation Phase learners at disadvantaged primary schools. As schools do not have the necessary fenced playgrounds for Foundation Phase learners, equipment is being used by the older children and not for its specific purpose.

School principals in conjunction with the community can attempt to better equip playgrounds, more specifically, playgrounds for Grade R learners. Innovative Grade R teachers can, by means of workshops, obtain knowledge on how to make various playing apparatus and resources from waste materials (Peeters, 2008).

From the data in this article it is clear that diversity in the Republic of South Africa stretches further than its different population groups. The constitution gives each child the right to education. According to data collected in this study the following plays a big role, which limits or prevents the equal rights of certain Grade $\mathrm{R}$ learners: A deficiency in playing apparatus, resources and equipment in Grade R classes should also be addressed.

Children from privileged backgrounds enter the schooling system at greater advantage than children from impoverished homes. Due to the discrepancies between home and the school and negative schooling experiences, the vast majority of children in schools within impoverished neighbourhoods that provide a poor learning environment are disadvantaged. There is, therefore, a need to provide equal opportunities and access for all children (DoE, 2000, p. 12).

If the officials in educational and provincial head offices attend to findings and recommendations in articles such as this deficiencies within the education system regarding Grade $\mathrm{R}$ learners will be limited. 


\section{Conclusion}

In the results of the study it shows that teachers are not sufficiently trained for the early child developmental needs within the education environment. Many schools are under-supplied in terms of resources and equipment. The level of learning readiness of Grade R learners is determined by perceptual motor stimulation in the pre-school phase. It seems as the influence of knowledge and teaching experience of teachers and availability of teaching aids and equipment has an immense effect.

\section{References}

Brewer, J.A. (2007). Introduction to early childhood education. Pre-school through primary school. (6 $6^{\text {th }}$ ed.), p. 552. Boston: Pearson education, Inc. Allan \& Bacon.

Bronfenbremmer, U. \& Evans, D.E. (2000). Ecological systems theory. In R. Vasta (Ed.). Six theories of child development: Revised formulations and new new trends, $\mathrm{p}$. 187-249. London: Jessica Kingsley.

Center, Y. (1998). Skills for pre-school teachers. ( $6^{\text {th }}$ ed.). New Jersey: Merril Prentice Hall.

Coetzee, N.A.J. (1997). Perseptueel-motoriese ontwikkeling as opgaaf vir die kind in beweging. Tydskrif vir Christelike Wetenskap, 33(3/4), 55-61.

Cohen, L., Manion, L. \& Morrison, K. (2002). Research methods in education. ( $5^{\text {th }}$ ed.). Londen: Routledge Falmer.

Cools, W., De Martelaar, K., Samaey, C. \& Andries, C. (2009). Movement skill assessment of typically developing preschool children: A review of seven movement skill assessment tools. Journal of Sport science and medicine, 8(2), 154-168.

Cresswell, J.W. (2009). Research design. Quantative and mixed methods approach. (3 ${ }^{\text {rd }}$ ed.). Thousand Oaks, CA: Sage.

Davin, R. \& Van Staden, C. (2004). The reception year: Learning through play, p. 307. Sandton, Johannesburg: Heinemann.

Department of Higher Education and Training (DHET). (2009). Education students to complete studies end of 2009. Pretoria: Government Printers.

Department of National Education. (1995). White paper on Education and Training. Pretoria: Government printers.

Departement van Nasionale Onderwys. (2002). Hersiene nasionale kurrikulumverklaring Graad R - 9. Lewensoriëntering. Pretoria: Staatsdrukkers.

Departement van Nasionale Onderwys. (2003). Hersiene nasionale kurrikulumverklaring Graad R - 9. Grondslagfase. Gids vir ontwikkeling van leerprogramme. Pretoria: Staatsdrukkers.

Department of National Education. (2007). National Education Law. Education Law and Policy Handbook. In: South African Schools Act. Pretoria: Government Printers. 
Department of National Education. (2008). Minister of Education, N. Pandor official release of the learner achievement results from the systematic evaluation (Grade 3) survey of 2007. 6 November, Sol Plaatjie Building, Pretoria.

Department of National Education. (2008). Education for All (EFA). Country report. Pretoria, South Africa.

De Witt, M.W. (2009). The young child in context. A thematic approach. Perspectives from educational psychology and socio-pedagogics, p. 374-7. Pretoria: Van Schaik.

Donald, D.L., Lazarus, S. \& Lolwana, P. (2002). Educational psychology in social context. Cape Town: Oxford University Press.

Ellis, S.M. \& Steyn, H.S. (2003). Practical significance (effect sizes) versus or in combination with statistical significance ( $p$-values). Management Dynamics, 12(4), 51-53.

Erasmus, M. (2008). Observation by researcher while doing research at disadvantaged primary and nursery schools, Ikageng, South Africa.

Gallahue, D.L. \& Ozmun, J.C.(1995). Understanding motor development, infants, children, adolescents, adults. ( $3^{\text {rd }}$ ed.). Madison, WI: WCB Brown \& Benchmark.

Gallahue, D.L. \& Ozmun, J.C. (1995). Understanding motor development. Madison: WCB Brown \& Benchmark.

Goodway, J.D. \& Branta, C.F. (2003). Influence of a motor skill intervention on fundamental motor development of disadvantaged pre-school children. Research quarterly for exercise and sport, 74(1), 36-46.

Govender, P. (2011, 24 July). We don't want to teach little kids. Sunday Times, p. 10.

Greyling, S. (2011, February). Grade R need to keep their identity in public primary schools. Paper presented at the Early Childhood Conference, North-West Province.

Grobler, H.M., Faber, R.J., Orr, J.P., Calitz, E.M. \& Catitz, C.J.S. (1998). The day-care handbook, p. 184. Pretoria: Kagiso Publishers.

Grove, M.C. \& Hauptfleisch, H.M.A.M. (1978). Perseptuele ontwikkeling. Handleiding, p. 184. Pretoria: De Jager-HAUM.

Kartal, H. (2007). Investment for the future: Early childhood development and education. Educational Sciences: Theory and Practice, 7(1), 543-554.

Labucshagne, G.M. (2006). Die motoriese en sensoriese ontwikkeling van vyf- tot sesjarige kinders in swak sosio-ekonomiese omstandighede: Thusano-studie. MA verhandeling, NWU, Potchefstroom, South Africa.

Leedy, P.D. \& Ormond, J.E. (2005). Practical research: Planning and design. ( $8^{\text {th }}$ ed.). Upper Saddle River, New York: Merril Prentice Hall.

Lenyai, E. (2009). The design and implementation of intervention programmes for disadvantaged school beginners. Unpublished doctoral dissertation, University of South Africa.

Lenyai, E. \& De Witt, M. (2009). Language practices in school-based Grade R classrooms. Journal of language teaching, 42(2), 78-88. 
Mcafee, O. \& Leong, D.J. (2002). Assessing and guiding young learners' development and learning. ( $3^{\text {rd }}$ ed.). Boston: Allyn \& Bacon.

Moss, P. (2000). Training of early childhood education and care staff. International Journal of Educational Research, 33, 31-53.

Pandor, N. (2008). Address to the Foundation Phase Conference held at the? Mokopane, Limpopo Province, 30 September-1 October 2008.

Peeters, C. (2008). Low-cost ways of improving quality in early childhood education. Early Childhood Matters, June 2008.

Pienaar, A.E. (2008). Kinderkinetika: 'n Belegging in die totale welstand van kinders. NWU. Oktober 2008. Wetenskaplike bydra, Reeks H: Intreerede nr. 221.

Rademeyer, A. (2009, 27 November). Gehalte van voorskoolse onderrig kwel. Die Volksblad, p. 6.

Rademeyer, A. (2010, 18 Maart). Kommer oor Graad R onderrig se gehalte. Beeld, p. 4.

Republic of South Africa. (1997). Department of Education policy document, Foundation Phase (Grades R to 3). Pretoria: Government Printers.

Republic of South Africa. (2007). Department of Education National Policy: Education. White Paper 5 on early childhood development. Pretoria: Government Printers.

Robinson, M. (2011, 24 July). We don't want to teach little kids - Dean of Cape Peninsula University of Technology. Sunday Times, p. 10.

Serrao, A. (2008, 7 November). Only 36\% of Grade 3 learners can read. The Star, p. 8.

Shula, P., Chaya, S., Jeri, H.M. \& Noomi, K. (2000). Perceptual, motor and cognitive performance components of Bedouin children in Israel. Occupational Therapy International, 7(4), 216-231.

South African National Tutor Services (SANTS). (2006). Early Childhood Education training for educators. Pretoria: Business Print.

Steyn, M.G. \& Hartell, C.G. (2011). Where are the Foundation Phase teachers for our children? Black students' perception. Paper delivered at the Early Childhood Conference, 1-3 February 2011. Potchefstroom, North-West Province.

Van Zyl. E. (2004). The relation between perceptual development (as part of school readiness) and school success of Grade 1 learners. Africa Education review, 1(1), 147-159.

Washington, V. \& Oyemade, U.J. (1995). Project Headstart: Models and strategies for the $21^{\text {st }}$ century. New York: Garland.

Wilkins, F., Van Zijl, M., De Meyer, E. \& Grobbelaar, M. (2003). ACE Grade R Learning Programme: Literacy, Numeracy, Life Skills. Cape Town: Juta Gariep (Pty) Ltd.

Willenberg, I. (2005). Starting at the beginning: Early childhood intervention as a strategy for reducing adult illiteracy. Language Matters: Studies in the Languages of South Africa, 36(2), 162-175.

Zuma, J. (2009). State of the nation address held at the joint sitting of the parliament, Cape Town, 10 February 2009. 